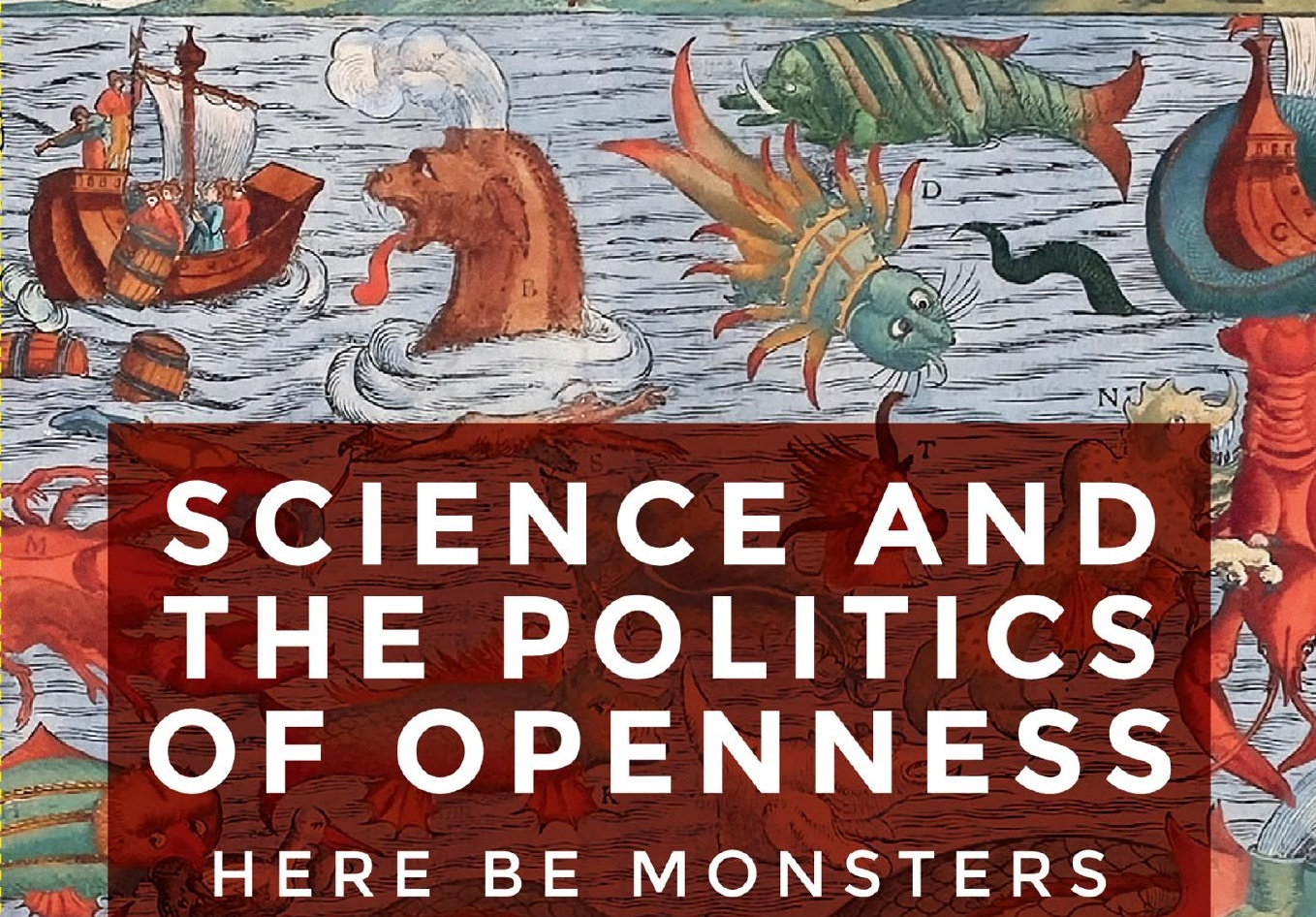




\section{Science and the politics of openness}

\section{MANCHESTER 1824}

Manchester University Press 
Brigitte Nerlich, Sarah Hartley, Sujatha Raman, and Alexander Smith - 9781526106476 Downloaded from manchesterhive.com at 04/26/2023 02:41:41PM 


\section{Science and the politics of openness}

Here be monsters

Edited by Brigitte Nerlich, Sarah Hartley, Sujatha Raman and Alexander Smith

Manchester University Press 
Copyright $\odot$ Manchester University Press 2018

While copyright in the volume as a whole is vested in Manchester University Press, copyright in individual chapters belongs to their respective authors.

This electronic version has been made freely available under a Creative Commons (CC-BY-NC-ND) licence, which permits non-commercial use, distribution and reproduction provided the author(s) and Manchester University Press are fully cited and no modifications or adaptations are made. Details of the licence can be viewed at https://creativecommons.org/licenses/by-nc-nd/3.0/

Published by Manchester University Press

Altrincham Street, Manchester M1 7JA

www.manchesteruniversitypress.co.uk

British Library Cataloguing-in-Publication Data

A catalogue record for this book is available from the British Library

ISBN 9781526106469 hardback

ISBN 9781526106476 open access

First published 2018

The publisher has no responsibility for the persistence or accuracy of URLs for any external or third-party internet websites referred to in this book, and does not guarantee that any content on such websites is, or will remain, accurate or appropriate.

Typeset

by Toppan Best-set Premedia Limited 